\title{
PENGARUH PENAMBAHAN INOKULUM, LAMA FERMENTASI DAN PENGADUKAN PADA PEMBUATAN VIRGIN COCONUT OIL (VCO) MENGGUNAKAN KHAMIR SACCHAROMYCES CEREVISIAE MURNI
}

\author{
Jernika Simangunsong, Elisa Febrina*, Zuhrina Masyithah \\ Departemen Teknik Kimia, Fakultas Teknik, Universitas Sumatera Utara, \\ Jl. Almamater Kampus USU Medan 20155, Indonesia \\ *Email: elisafebrina92@yahoo.com
}

\begin{abstract}
Abstrak
Minyak kelapa murni atau Virgin Coconut Oil (VCO) merupakan minyak kelapa yang diproses tanpa pemanasan. Pada penelitian ini digunakan metode fermentasi dengan menggunakan khamir Saccharomyces cerevisiae. Tujuan dari penelitian ini adalah mengetahui kondisi terbaik yaitu pengaruh pengadukan, waktu fermentasi dan konsentrasi inokulum pada proses pembuatan VCO. Kecepatan pengadukan yang digunakan yaitu $25 \mathrm{rpm}, 50 \mathrm{rpm}, 75 \mathrm{rpm}, 100 \mathrm{rpm}$ dan $125 \mathrm{rpm}$. Waktu pengadukan yang digunakan yaitu 15 menit, 30 menit, 45 menit, 60 menit dan 75 menit. Waktu fermentasi yang digunakan adalah mulai dari 6 jam, 12 jam, 18 jam dan konsentrasi inokulum 5\%, $10 \%, 15 \%, 20 \%, 25 \%$. Untuk pengaruh pengadukan, rendemen tertinggi diperoleh sebesar $24,5 \%$ dengan kecepatan pengadukan $50 \mathrm{rpm}$ dengan waktu pengadukan 30 menit dan rendemen terendah yaitu 8,5\% dengan kecepatan pengadukan $100 \mathrm{rpm}$ dengan waktu pengadukan 75 menit. Untuk pengaruh lama fermentasi dan penambahan inokulum, rendemen VCO tertinggi yang diperoleh $28,25 \%$ dengan kondisi waktu fermentasi 24 jam dan konsentrasi inokulum sebesar $10 \%$ dan rendemen terendah sebesar $15 \%$ dengan lama fermentasi 12 jam dengan konsentrasi inokulum $20 \%$. Hasil yang diperoleh untuk pengaruh pengadukan menunjukkan penurunan terhadap rendemen VCO dan waktu fermentasi menunjukkan penambahan rendemen VCO serta konsentrasi inokulum tidak berpengaruh terhadap rendemen VCO.
\end{abstract}

Kata Kunci : VCO, saccharomyces cerevisiae, fermentasi, pengadukan, santan kelapa

\begin{abstract}
Virgin coconut oil (VCO) is coconut oil that processed without heating. This study about fermentation of VCO using Saccharomyces cerevisiae. The purposes of this research is to find the best condition like stirring times, stirring speeds, fermentation times and concentration of inoculum in the process of making VCO. The variation of stirring speeds are $25 \mathrm{rpm}, 50 \mathrm{rpm}, 75 \mathrm{rpm}, 100 \mathrm{rpm}$ and $125 \mathrm{rpm}$. Stirring time used was 15 minutes, 30 minutes, 45 minutes, 60 minutes and 75 minutes. The variation of fermentation times are 6 hours, 12 hours, 18 hours, 24 hours, and 30 hours and variation concentration of inoculum are 5\%,10\%,15\%,20\% and 25\%. For stirring effects, the highest yield was obtained 24,5\% with stirring speed is $50 \mathrm{rpm}$ and stirring time is 30 minutes and the lowest yield was obtained $8,5 \%$ with stirring speed is $100 \mathrm{rpm}$ and stirring time 75 minutes. For fermentation times and concentration inoculum effets, the highest yield was obtained from this research is $28,25 \%$ with addition inoculum is $10 \%$ and fermentation times is 24 hours. And the lowest yield is $15 \%$ with addition inoculum is $20 \%$ and fermentation times is 12 hours. The results of this research for stirring effects showed decreases yield of VCO and for the fermentation time showed increases yield of VCO and concentration inoculum showed no effect for yield of VCO.
\end{abstract}

Keywords : VCO, saccharomyces cerevisiae, fermentation, stirring, coconut milk

\section{Pendahuluan}

Indonesia merupakan negara tropis yang memiliki banyak pulau dan merupakan negara produsen kelapa utama di dunia. Hampir di semua propinsi di Indonesia dijumpai tanaman kelapa yang pengusahaannya berupa perkebunan rakyat. Hal ini merupakan peluang untuk pengembangan kelapa menjadi aneka produk yang bermanfaat [9].

Kelapa memiliki peran yang strategis bagi masyarakat Indonesia dan termasuk sembilan bahan pokok masyarakat. Produksi kelapa Indonesia per tahun menempati urutan kedua di dunia yakni sebesar 12.915 milyar butir $(24,4 \%)$ produksi dunia. Namun permasalahan dari komuditas tersebut bukan pada luas lahan dan jumlah produksi tetapi produk yang dihasilkan masih terbatas pada bentuk produk primer sehingga tidak kompetitif. Umumnya, produk kelapa di Indonesia dipasarkan dalam bentuk primer atau belum diolah lebih lanjut. Ini menyebabkan nilai ekonomis kelapa menjadi rendah [1].

Dalam minyak kelapa murni atau virgin coconut oil (VCO) terkandung energi sebanyak 6,8 kal/gr dan medium chain fatty acid (MCFA) sebanyak 92\% [7]. VCO mampu mendukung 
sistem kekebalan dengan membebaskan tubuh dari mikroorganisme berbahaya [5].

Santan merupakan emulsi minyak dalam air alami berwarna putih susu yang diekstrak dari daging buah kelapa tua baik dengan atau tanpa penambahan air. Bagian yang kaya dengan minyak disebut sebagai krim dan bagian yang miskin dengan minyak disebut dengan skim [20].

Pembuatan VCO memiliki banyak keunggulan yaitu tidak membutuhkan biaya yang mahal karena bahan baku mudah didapat dengan harga yang murah, pengolahan yang sederhana dan tidak terlalu rumit serta penggunaan energi yang minimal karena tidak menggunakan bahan bakar sehingga kandungan kimia dan nutrisinya tetap terjaga terutama asam lemak dalam minyak [9].

VCO mengandung asam laurat yang tinggi (45-55) \%, disamping itu juga mengandung asam lainnya. VCO memiliki manfaat yang sangat banyak yakni berkhasiat bagi kesehatan tubuh [1]. Selain itu, VCO juga merupakan pelembab kulit alami karena mampu mencegah kerusakan jaringan dan memberikan perlindungan terhadap kulit [20].

\section{Teori}

Kelapa atau Cocos nucifera termasuk tumbuhan berkeping satu suku palem-paleman. Tinggi tanaman ini dapat mencapai 20 sampai 25 meter [3].

VCO merupakan minyak kelapa murni yang terbuat dari daging kelapa segar yang diolah dalam suhu rendah atau tanpa melalui pemanasan [13]. VCO mengandung asam laurat yang tinggi (45-55) \%. Pada Tabel 1 dapat dilihat standar mutu VCO menurut SNI.

Tabel 1. Standar Mutu VCO menurut SNI [21]

\begin{tabular}{|l|l|}
\hline \multicolumn{1}{|c|}{ Karakteristik } & \multicolumn{1}{c|}{ Kandungan } \\
\hline Kadar air & $\leq 0,2$ \\
Bilangan Peroksida (mgO2/kg) & $\leq 2,0$ \\
Bilangan iod (mg KOH/sampel) & $4,1-11,0$ \\
Bilangan Asam (mg KOH/sampel) & $\leq 10$ \\
Kadar ALB (\%) & $\leq 0,2$ \\
Warna & Tidak \\
& berwarna \\
\hline
\end{tabular}

\section{Metodologi Penelitian \\ Bahan dan Alat}

Adapun bahan yang digunakan dalam penelitian ini adalah santan kelapa, khamir Saccharomyces cerevisiae, air, kalium Hdroksida $(\mathrm{KOH})$, asam klorida (HCL), phenolptalein, asam asetat $\left(\mathrm{CH}_{3} \mathrm{COOH}\right)$, kloroform, natrium thiosulfat dan kalium iodida.

Alat yang digunakan dalam penelitian ini yaitu shaker, beaker gelas, gelas ukur, neraca digital, erlenmeyer, kertas saring, piknometer dan kromatografi gas.

\section{Persiapan Bahan Baku Santan Kelapa}

Daging kelapa segar dipilih dan diparut, lalu ditambahkan air kedalam kelapa parut dengan perbandingan 1:1,5 (b/v) lalu mengambil santannya. Selanjutnya santan disaring dari ampas kelapa lalu didiamkan selama 30 menit hingga terbentuk 2 lapisan yaitu lapisan bawah (air) dan lapisan atas (krim) kemudian dipisahkan dengan corong pemisah lalu diambil krimnya.

\section{Pembuatan VCO}

Sebanyak $400 \mathrm{ml}$ santan ditampung dalam toples transparan lalu menambahkan inokulum dengan konsentrasi sesuai variabel yaitu 5\%, $10 \%, 15 \%, 20 \%$ dan $25 \%$ (v/v). sambil diaduk selama 15 menit, 30 menit, 45 menit, 60 menit dan 75 menit dengan kecepatan pengadukan 25 rpm, $50 \mathrm{rpm}, 75 \mathrm{rpm}, 100 \mathrm{rpm}$ dan $125 \mathrm{rpm}$. Selanjutnya didiamkan selama 6 jam, 12 jam, 18 jam, 24 jam dan 30 jam (sesuai variabel) hingga terbentuk 3 lapisan. Lapisan atas merupakan VCO, lapisan tengan adalah blondo dan lapisan bawah adalah air. Kemudian memisahkan VCO dari air dan blondo lalu dilakukan perhitungan rendemen VCO.

\section{Analisa}

Analisa yang dilakukan berupa analisa kualitatif dan analisa kuantitatif. Analisa kualitatif meliputi penampilan, warna dan bau. Analisa kuantitatif meliputi analisa rendemen VCO, analisa asam lemak bebas (ALB). Analisa kadar air, analisa bilangan peroksida, analisa bilangan iodin, analisa densitas dan analisa gas kromatografi.

\section{Hasil dan Pembahasan Analisa Kualitatif}

Pada Tabel 2 dapat dilihat hasil analisa kualitatif yang diperoleh yaitu penampilan berupa cairan jernih dengan aroma kelapa segar.

Tabel 2. Hasil Analisa Kualitatif VCO

\begin{tabular}{|l|l|}
\hline \multicolumn{1}{|c|}{ Karakteristik } & \multicolumn{1}{c|}{ Pengamatan } \\
\hline Penampilan & Cairan \\
Warna & Jernih (tidak berwarna) \\
Bau & Wangi kelapa segar \\
\hline
\end{tabular}

Hasil penelitian analisa kualitatif yang diperoleh pada penelitian ini juga sejalan dengan hasil penelitian yang dilakukan Nely yaitu VCO yang jernih (tidak berwarna) dan memiliki aroma kelapa segar [12]. 


\section{Analisa Kuantitatif}

\section{Pengaruh Waktu fermentasi Terhadap} Rendemen VCO

Pada Gambar 1 dapat dilihat semakin lama waktu fermentasi yang dilakukan maka rendemen VCO cenderung semakin menigkat. Namun pada penelitian ini terjadi penurunan perolehan rendemen minyak pada waktu 30 jam. Menurut Juwita, semakin lama fermentasi maka asam yang dihasilkan akan lebih banyak [15].

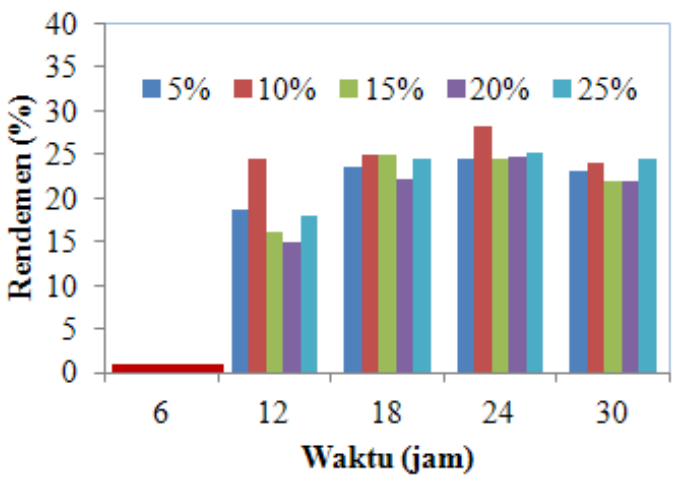

Gambar 1. Pengaruh Waktu Fermentasi Terhadap Rendemen VCO

Proses terjadinya penurunan $\mathrm{pH}$ dapat terjadi dari awal fermentasi diakibatkan terbentuknya asam-asam selama proses fermentasi berlangsung.

Hasil penelitian yang diperoleh memperlihatkan bahwa waktu ekstraksi selama 6 jam belum menghasilkan VCO. Dari grafik di atas dapat dilihat bahwa rendemen tertinggi diperoleh saat fermentasi dilakukan selama 24 jam.

\section{Pengaruh Konsentrasi Inokulum terhadap} Rendemen VCO

Pada gambar 2 dapat dilihat pengaruh konsentrasi inokulum terhadap rendemen VCO.

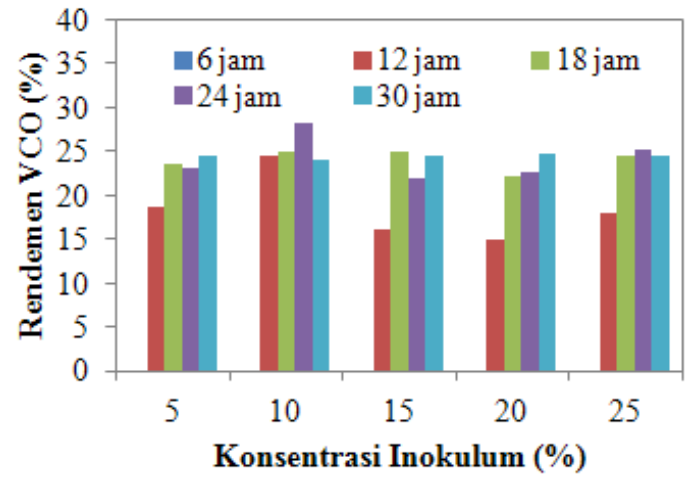

Gambar 2. Pengaruh Konsentrasi inokulum Terhadap Rendemen VCO
Menurut Ngatemin semakin tinggi konsentrasi inokulum yang digunakan maka rendemen yang diperoleh juga akan semakin naik (besar). Hal ini dikarenakan enzim yang berasal dari Saccharomyces cerevisiae adalah enzim proteolitik yang dapat menghidrolisis ikatan peptida [13].

Namun pada penelitian ini berbeda dengan yang dilaporkan oleh Ngatemin. Dimana penambahan inokulum tidak begitu berpengaruh terhadap rendemen VCO. Hal ini diduga bahwa penambahan Saccharomyces cerevisiae sudah tidak seimbang dengan sumber makanan yang tersedia dalam santan kelapa yang akan difermentasi sehingga khamir mulai kekurangan makanan sehingga yang terjadi adalah khamir saling memakan satu sama lain

\section{Analisa Asam Lemak Bebas (ALB) VCO Pengaruh Waktu Fermentasi Terhadap ALB VCO}

Pada gambar 3 dapat dilihat pengaruh waktu fermentasi terhadap ALB VCO. Semakin lama waktu fermentasi maka semakin tinggi ALB yang terkandung dalam VCO. Hal ini disebabkan karena kandungan air dalam VCO meningkat dan adanya enzim lipase yang berperan dalam pembentukan asam lemak bebas. Proses penting terbentuknya asam lemak bebas yaitu proses hidrolisis yang akan melepaskan asam lemak rantai pendek yang dapat menyebabkan timbulnya bau. Dengan adanya air, lemak akan terhidrolisis membentuk gliserol dan asam lemak bebas [13].

Hasil yang diperoleh memperlihatkan bahwa semakin lama waktu fermentasi, maka kandungan asam lemak bebasnya semakin besar.

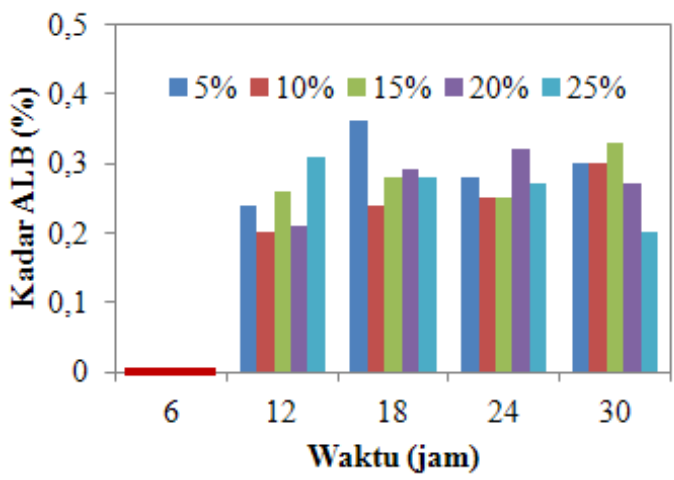

Gambar 3. Pengaruh Waktu fermentasi Terhadap ALB VCO

Menurut SNI, kadar ALB maksimal yang terkandung dalam $\mathrm{VCO}$ yaitu $0,2 \%$ sedangkan menurut APCC kadar ALB maksimal yang terkandung dalam VCO yaitu 0,5\%. Dari hasil 
penelitian terlihat bahwa kadar ALB masih sesuai standart menurut $[2,21]$.

\section{Pengaruh Konsentrasi Inokulum Terhadap ALB VCO}

Pada gambar 4 dapat dilihat pengaruh konsentrasi inokulum terhadap ALB VCO.

Semakin banyak penambahan ragi roti (Saccharomyces cerevisiae) maka ALB semakin tinggi [15].

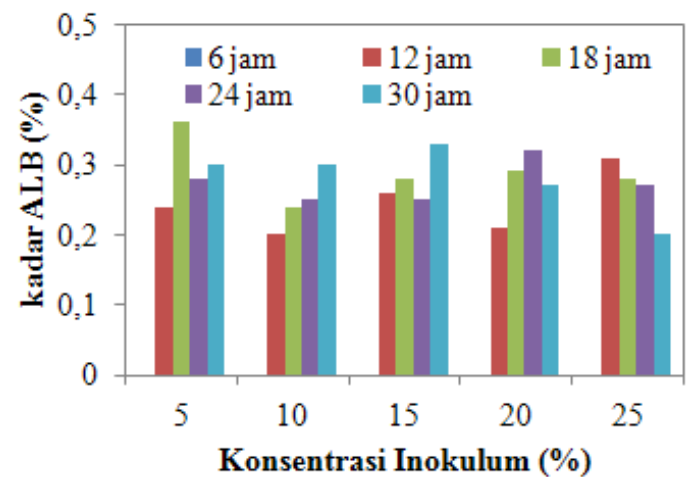

Gambar 4. Pengaruh Konsentrasi Inokulum Terhadap ALB VCO

Dari gambar 4 peningkatan ALB VCO yang didapat juga dapat dilihat dari meningkatnya konsentrasi inokulum yang digunakan untuk mengekstrak VCO. Menurut [20], kadar ALB maksimal yang terkandung dalam VCO yaitu $0,5 \%$. Dari hasil penelitian terlihat bahwa kadar ALB masih sesuai standar.

\section{Pengaruh Waktu Pengadukan Terhadap Rendemen Minyak Kelapa Murni}

Pada gambar 5 dapat dilihat bahwa rendemen minyak kelapa murni yang dihasilkan untuk berbagai macam kecepatan pengadukan yang cenderung menurun dengan peningkatan waktu pengadukan kecuali pada $125 \mathrm{rpm}$.

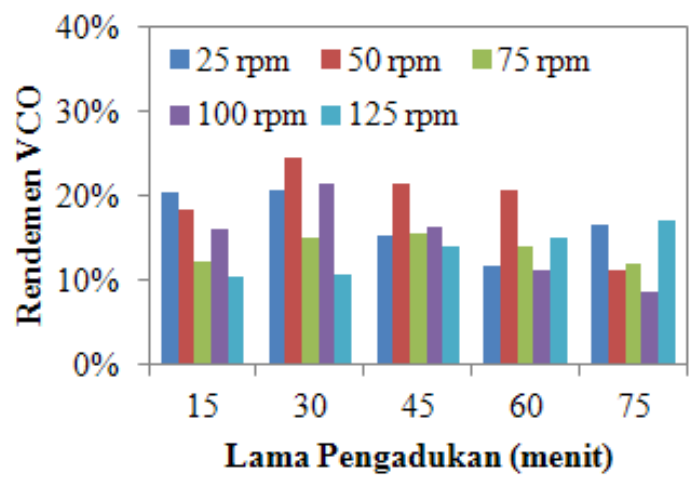

Gambar 5. Pengaruh Waktu Pengadukan Terhadap Rendemen Minyak Kelapa Murni
Rendemen minyak kelapa murni cenderung meningkat dengan peningkatan waktu pengadukan. Hasil penelitian yang diperoleh memperlihatkan bahwa waktu pengadukan selama 15 menit menghasilkan rendemen minyak kelapa murni $(10,75-20,5) \%$, sementara 30 menit pengadukan menghasilkan rendemen minyak kelapa murni $(10,5-24,5) \%, 45$ menit (14-21,5) \%, 60 menit $(11,75-20,75) \%$ dan 75 menit memberikan rendemen minyak kelapa murni $(8,5-17) \%$.

Dari data tersebut dapat dilihat bahwa semakin lama waktu pengadukan yang dilakukan maka rendemen minyak kelapa murni cenderung semakin menurun. Rendemen tertinggi diperoleh saat pengadukan dilakukan selama 30 menit.

\section{Pengaruh Kecepatan Pengadukan Terhadap Rendemen Minyak Kelapa Murni}

Pada gambar 6 dapat dilihat pengaruh kecepatan pengadukan terhadap rendemen minyak kelapa murni pada masing-masing perlakuan. Hasil penelitian yang diperoleh memperlihatkan bahwa kecepatan pengadukan menghasilkan rendemen minyak kelapa murni $11,75-20,75 \%$ pada $25 \mathrm{rpm}, 11,25-24,5 \%$ pada $50 \mathrm{rpm}, 12-15,5 \%$ pada $75 \mathrm{rpm}, 8,5-21,5 \%$ pada $100 \mathrm{rpm}$ dan $10,5-17 \%$ pada $125 \mathrm{rpm}$.

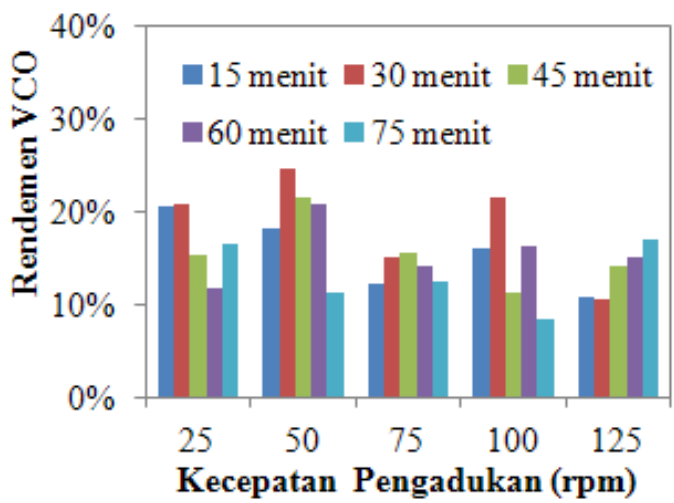

Gambar 6. Pengaruh Kecepatan Pengadukan Terhadap Rendemen Minyak Kelapa Murni

Dari data tersebut dapat dilihat bahwa semakin cepat pengadukan yang dilakukan maka rendemen minyak kelapa murni cenderung menurun. Rendemen tertinggi diperoleh saat kecepatan pengadukan dilakukan selama $50 \mathrm{rpm}$.

Pengaruh Waktu dan Kecepatan Pengadukan Terhadap Kadar ALB Minyak Kelapa Murni

Pada gambar 7 dapat dilihat bahwa ALB VCO yang dihasilkan untuk berbagai macam kecepatan pengadukan yang cenderung menurun dengan peningkatan waktu pengadukan. 


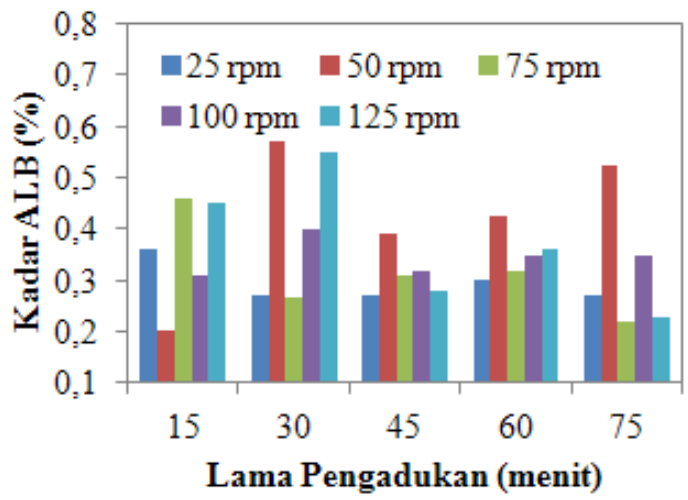

Gambar 7. Pengaruh Waktu Pengadukan Terhadap Kadar ALB Minyak Kelapa Murni

Pada gambar 8 dapat dilihat bahwa ALB minyak kelapa murni yang dihasilkan untuk berbagai macam waktu pengadukan yang cenderung meningkat dengan peningkatan kecepatan pengadukan.

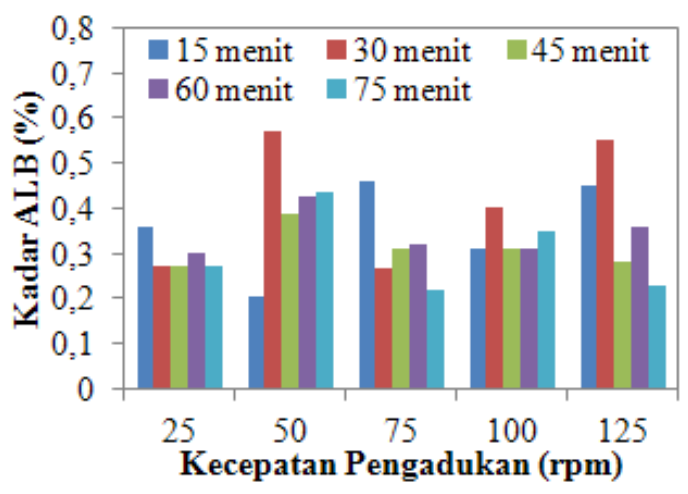

Gambar 8. Pengaruh Kecepatan Pengadukan Terhadap Kadar ALB Minyak Kelapa Murni

Menurut SNI kadar ALB maksimal yang terkandung dalam minyak kelapa murni yaitu 0,2 $\%$ sedangkan menurut APCC kadar ALB maksimal yang terkandung dalam minyak kelapa murni yaitu $0,5 \%$. Dari hasil penelitian terlihat bahwa kadar ALB masih sesuai standart menurut APCC [2].

\section{Analisa Kadar Air VCO}

Kadar air yang diperoleh pada rendemen VCO 28,25\% yaitu sebesar $0,25 \%$ dan pada rendemen VCO $15 \%$ diperoleh kadar air sebesar $0,239 \%$. Kadar air yang diperoleh pada rendemen $24,5 \%$ yaitu sebesar $1,157 \%$ dan pada rendemen $8,5 \%$ diperoleh kadar air sebesar $0,719 \%$

Menurut standar Philipina kadar air yang diperbolehkan pada VCO maksimal 0,1\%. Pada penelitian ini kadar air yang diperoleh melebihi standar yang diperbolehkan yang berarti bahwa
VCO masih belum sesuai dengan standar yang ada. Kadar air yang tinggi bisa dikarenakan bercampurnya air pada saat pembuatan dan tidak bisa dipisahkan dengan metode pemisahan biasa [10].

\section{Analisa Bilangan Peroksida}

Menurut Augustyn penyebab terjadinya kenaikan angka peroksida yaitu banyaknya air yang terkandung dalam santan dan molekulmolekul minyak atau yang mengandung radikal asam lemak tidak jenuh sehingga mengalami oksidasi dan menjadi tengik [4].

Bilangan peroksida yang diperoleh pada rendemen VCO $28,25 \%$ yaitu sebesar $0,4 \mathrm{meq} / \mathrm{kg}$ dan pada rendemen VCO $15 \%$ diperoleh bilangan peroksida sebesar $1 \mathrm{meq} / \mathrm{kg}$. Sedangkan bilangan peroksida yang diperoleh pada rendemen 24,5\% yaitu sebesar 1,6 dan pada rendemen $8,5 \%$ diperoleh $1,4 \mathrm{meq} / \mathrm{kg}$.

Menurut standar APCC (Asian and Pacific Coconut Community) untuk VCO bilangan peroksida VCO yang diperbolehkan adalah maksimal $3 \mathrm{meq} / \mathrm{kg}$. Maka dapat disimpulkan bahwa bilangan peroksida pada penelitian ini masih sesuai standar yang ada.

\section{Analisa Bilangan Iodin}

Banyaknya iod yang diikat menunjukkan banyaknya ikatan rangkap. Angka iod dinyatakan sebagai banyaknya gram iod yang diikat oleh 100 gram minyak atau lemak [6].

Untuk rendemen VCO 28,25\% bilangan iod yang diperoleh sebesar 9,2406 dan pada rendemen VCO terendah $15 \%$ memiliki bilangan iod sebesar 8,8441. Sedangkan bilangan iod yang diperoleh pada rendemen $24,5 \%$ yaitu sebesar 10,3025 dan pada rendemen 8,5\% diperoleh 9,4937.

Pada standar APCC bilangan iod VCO yang diperbolehkan adalah sebesar 4,1-11. Jika dilihat dari standar yang ada yaitu SNI dan standar APCC, besarnya bilangan iodin yang diperoleh pada penelitian ini masih sesuai dengan standar VCO yang sudah ditentukan.

\section{Analisa Densitas VCO}

Massa jenis merupakan salah satu parameter yang digunakan untuk menentukan kualitas suatu minyak, semakin tinggi nilai massa jenis maka kualitas minyak tersebut rendah, hal ini dikarenakan kenaikan massa jenis dipengaruhi asam lemak bebas [16].

Menurut Asian and Pacific Coconut Community (APCC) untuk VCO menyebutkan bahwa relative densitiy dari $\mathrm{VCO}$ yang diperbolehkan adalah 0,915-0,920 [2]. 
Pada penelitian ini analisa densitas hanya dilakukan pada perolehan rendemen VCO tertinggi dan terendah. Untuk rendemen VCO tertinggi diperoleh densitas VCO sebesar 0,9061 dan densitas untuk rendemen VCO terendah sebesar 0,9239 .

Jika dilihat dari standar yang ada maka densitas VCO yang diperoleh pada penelitian ini masih tidak sesuai dengan standar yang diperbolehkan. Hal ini dikarenakan oleh karakterisitk air minyak serta zat-zat yang lolos pada saat penyaringan minyak seperti kotoran, protein, garam mineral yang dapat mempengaruhi besarnya berat jenis minyak [8].

\section{Analisa Gas Kromatografi}

Dalam hal ini kandungan asam lemak tertinggi yang terdapat pada VCO adalah asam laurat. Dimana pada penelitian ini analisa GC dilakukan pada rendemen tertinggi dan terendah. Dimana pada rendemen tertinggi kandungan asam lauratnya sebesar $48,3 \%$ dan pada rendemen terendah sebesar 50,08\%. Menurut SNI kandungan asam laurat yang diperbolehkan adalah 45,1-53,2\%. Maka dapat disimpulkan bahwa kandungan asam laurat pada penelitian ini masih sesuai dengan standar yang ada.

\section{Kesimpulan}

Adapun kesimpulan yang dapat diambil dari penelitian yang telah dilakukan adalah bahwa penambahan konsentrasi inokulum tidak terlalu berpengaruh terhadap rendemen VCO tetapi sangat mempengaruhi karakteristik dari VCO. Namun rendemen VCO meningkat seiring dengan bertambahnya waktu fermentasi.

Rendemen minyak kelapa murni dan kadar asam lemak bebas (ALB) yang diperoleh cenderung semakin menurun seiring dengan bertambahnya waktu pengadukan sedangkan rendemen minyak kelapa murni yang diperoleh cenderung semakin menurun seiring dengan bertambahnya kecepatan pengadukan

Rendemen tertinggi diperoleh pada penambahan inokulum $10 \%$ dan waktu fermentasi 24 jam yakni sebesar 28,25\% dan rendemen terendah sebesar $15 \%$ pada penambahan inokulum $20 \%$ pada waktu fermentasi 12 jam.

Rendemen minyak kelapa murni tertinggi yang diperoleh yaitu $24,5 \%$ pada penambahan waktu pengadukan 30 menit dan pada kecepatan pengadukan $50 \mathrm{rpm}$. Sedangkan rendemen terendah yang diperoleh sebesar $8,5 \%$ pada waktu pengadukan 75 menit pada kecepatan pengadukan $100 \mathrm{rpm}$

\section{Daftar Pustaka}

[1] A. Rasyidi Fachry, Andre Oktarian dan Wahyu Wijanarko, "Pembuatan Virgin Coconut Oil dengan Metode Sentrifugasi”, Seminar Nasional Teknik Kimia Indonesia, Jurusan Teknik Kimia, Fakultas Teknik, Universitas Sriwijaya, Palembang, 2006.

[2] Asian and Pacific Coconut Community (APCC), "Standards for Virgin Coconut Oil", 2012.

[3] A.Tarore, M.R. Kereh dan D. Adipati, "Studi Kandungan Merkuri pada Daging Buah Kelapa di Tempat Pengolahan Bijih Emas, Desa Tatelu Rondor Kecamatan Dimembe Kabupaten Minahasa", Universitas Sam Ratulangi, Manado, Vol .2, No 1 (2002).

[4] Augustyn, G.H., "Pengaruh Penambahan Ekstrak Buah Pepaya (Carica papaya L.) Terhadap Mutu Minyak Kelapa Murni”, Program Studi Teknologi Hasil Pertanian, Fakultas Pertanian, Universitas Pattimura, Vol 8, No 1 (2012).

[5] Didik Purwanto, "Pengaruh Desain Impeller, Baffle dan Kecepatan Putar pada Proses Isolasi Minyak Kelapa Murni Dengan Metode Pengadukan”, Seminar Nasional Aplikasi Sains dan Teknologi, Jurusan Teknik Kimia, Institut Teknologi Adhi Tama Surabaya (ITATS), 2008.

[6] Firman Budiman, O. Ambari, A.H. Surest, "Pengaruh Waktu Fermentasi dan Perbandingan Volume Santan dan Sari Nanas pada Pembuatan Virgin Coconut Oil (VCO)", Universitas Sriwijaya, Vol 18, No 2 (2012).

[7] Henni Pujiati, "Sifat Antibakteri Hasil Hidrolisis Minyak Kelapa Murni terhadap Staphylococcus aureus dan Escherichia coli”, Skripsi, Fakultas Farmasi, Universitas Sumatera Utara, 2012.

[8] Intan deasy Ariwianti dan Kristina Ari Cahyani, "Pembuatan Minyak Kelapa dari Santan Secara Enzimatis Menggunakan Enzim Papain dengan Penambahan Ragi Tempe", Makalah Penelitian, Jurusan Teknik Kimia, Fakultas Teknik, Universitas Diponegoro, Semarang, 2008.

[9] Laras Cristianti, A.H. Prakosa, "Pembuatan Minyak Kelapa Murni (virgin coconut oil) Menggunakan Fermentasi Ragi Tempe", Tugas Akhir, Jurusan Teknik Kimia, Fakultas Teknik, Universitas Sebelas Maret, Surakarta, 2009.

[10] Mochamad Hadi Fadlana, "Pengaruh 
Suhu Penyimpanan dan Cara Ekstraksi Virgin Coconut Oil (VCO) terhadap Mutu Minyak yang Dihasilkan Selama Penyimpanan", Skripsi, Fakultas Teknologi Pertanian, Institut Pertanian Bogor, 2006.

[11] Mukhammad Asyari dan Bambang Cahyono, "Pra Standarisasi: Produksi dan Analisis Minyak Virgin Coconut Oil (VCO)", JSKA, Universitas Diponegoro Semarang, Vol 9, No 3 (2006).

[12] Nely Fatwatun R., K. Chusna dan B. Pramudono, "Pembuatan Virgin Coconut oil (VCO): Pemecahan Emulsi dengan Metode Ultrasonik", Jurusan Teknik Kimia, Fakultas Teknik, Universitas Diponegoro, Semarang, Vol 2, No 4 (2013).

[13] Ngatemin, Nurraham dan J.T. Isworo, "Pengaruh Lama Fermentasi pada Produksi Minyak Kelapa Murni (Virgin Coconut Oil) terhadap Sifat Fisik, Kimia, dan Organoleptik, Universitas Muhammadiyah Semarang, Vol 4, No 8 (2013).

[14] Rahayu Endah Nurani, "Pengaruh Waktu Fermentasi Saccharomyces cerevisiae terhadap Ketengikan dan Ketidakjenuhan pada Virgin Coconut Oil (VCO)", Skripsi, Fakultas Pendidikan Matematika Dan Ilmu Pengetahuan Alam, Program Studi Pendidikan Biologi, Ikip PGRI Semarang, 2013.

[15] Ratna Juwita, "Studi Produksi Alkohol dari Tetes Tebu (Saccharum officinarum L) Selama Proses Fermentasi", Skripsi, Jurusan Teknologi Pertanian, Fakultas Pertanian, Universitas Hasanuddin, Makassar, 2012.

[16] Riko Aditiya, H. Rusmarilin dan L.N. Limbong, "Optimasi Pembuatan Virgin Coconut Oil (VCO) dengan Penambahan Ragi Roti (Saccharomyces cerevisiae) dan Lama Fermentasi dengan VCO Pancingan", Program Studi Ilmu dan Teknologi Pangan Fakultas Pertanian USU Medan, Vol 2, No 2 (2014).

[17] Rommel Doloksaribu, Pengaruh Konsentrasi Starter Saccharomyces cereviceae dan Waktu Fermentasi terhadap Hasil dan Mutu Minyak Kelapa Virgin Coconut Oil", Tesis, Program Magister Biologi, Fakultas Matematika dan Ilmu Pengetahuan Alam, Universitas Sumatera Utara, Medan, 2010.

[18] Sapta Raharja dan Maya Dwiyuni, "Kajian Sifat Fisiko Kimia Ekstrak Minyak Kelapa Murni (Virgin Coconut
Oil, VCO) yang Dibuat dengan Metode Pembekuan Krim Santan", Departemen Teknologi Industri Pertanian, Fakultas Teknologi Pertanian, Institut Pertanian Bogor, Vol 18, No 2 (2012).

[19] Sukasih, "Optimasi Pembuatan Cocogurt (Yogurt Santan Kelapa) dengan Kultur Campuran Lactobacillus acidophilus moro dan Streptococcus thermophilus orla-jensen", Tesis, Program Studi Magister Bioteknologi SITH, Institut Teknologi Bandung, 2009.

[20] Sasniwiaty Sari Hasibuan, "Pengggunaan Minyak Kelapa Murni (VCO) Sebagai Pelembab dalam Sediaan Krim", Skripsi. Fakultas Farmasi, Universitas Sumatera Utara, Medan, 2011.

[21] SNI, Minyak Kelapa Virgin (VCO), Badan Standardisasi Nasional, 2008.

[22] Triastuti Rahayu, D. Widianto dan T. Yuwono, "Konstruksi Strain Haploid Saccharomyces cerevisiae Pembawa Kromosom XII yang Terpotong pada Sisi Kanan Lokus rDNA, Jurnal, Program Studi Bioteknologi Program Pascasarjana, Universitas Gadjah Mada (UGM), Yogyakarta, 2005.

[23] Yurnaliza, Pengaruh Variasi $\mathrm{pH}$ dan Konsentrasi Inokulum pada Produksi Minyak Kelapa secara Fermentasi, Departemen Biologi, Fakultas Matematika Dan Ilmu Pengetahuan Alam, Universitas Sumatera Utara, Vol 2, No 1 (2007). 